\title{
Yield and must composition of 'Cabernet Sauvignon' grapevines subjected to nitrogen application in soil with high organic matter content
}

\author{
Rendimiento y composición del mosto 'Cabernet Sauvignon' sometido \\ a aplicación de nitrógeno en suelos con alto contenido de materia orgánica \\ Lincon Oliveira Stefanello ${ }^{1}$, Raíssa Schwalbert ${ }^{1}$, Lessandro De Conti ${ }^{1}$, Adriele Tassinari ${ }^{1}$, \\ Luana Paula Garlet ${ }^{1}$, Cledimar Rogério Lourenzi ${ }^{2}$, Jucinei Comin ${ }^{2}$, Arcângelo Loss ${ }^{2}$, \\ Djalma Schmitt ${ }^{2}$, Marcelo Borghezan ${ }^{2}$, Vitor Ambrosini ${ }^{3}$ e Gustavo Brunetto
}

\begin{abstract}
It is common for vineyards in regions of high altitude to have high organic matter content in soil. Furthermore, reduced mineralization of organic matter and decomposing residues is expected because of the low temperatures. Thus, soils may not provide enough mineral nitrogen $(\mathrm{N})$ to meet the needs of the grapevines and so the application of $\mathrm{N}$ sources is necessary, but may affect yield and must composition. The study aimed to evaluate yield and must composition of grapevines subjected to $\mathrm{N}$ application in soil with high organic matter content and the relationship with temperature and rainfall. The study was conducted in crops seasons 2011/12, 2012/13 and 2013/14 in a vineyard located in the city of Água Doce, state of Santa Catarina, southern Brazil. The treatments consisted of $\mathrm{N}$ doses $\left(0,20,40,80\right.$ and $\left.120 \mathrm{~kg} \mathrm{~N}^{-1}\right)$ supplied via urea. Leaves opposite to the cluster were collected at full flowering and at veraison. Afterwards, the leaves were dried, ground and submitted to $\mathrm{N}$ analysis. Parameters of yield and must composition were evaluated. The dose of maximum technical efficiency in Cabernet Sauvignon grapevines was reached with $46 \mathrm{~kg} \mathrm{~N}^{-1}$ year $^{-1}$ in crop season 2012/13. Leaf $\mathrm{N}$ content was a sensitive parameter to the application of $\mathrm{N}$ doses in the soil and underwent seasonal variation in relation to rainfall distribution. The $\mathrm{N}$ doses reduced total soluble solids (TSS) contents in the must. Based on principal component analysis, we found a correlation between total $\mathrm{N}$ content in leaf and accumulated rainfall, as well as between yield and temperature.
\end{abstract}

Key words: nitrogen fertilization, leaf analysis, grape production, enological parameters, Vitis vinifera.

\section{RESUMEN}

Los viñedos ubicados en regiones altas poseen suelos con alto contenido de materia orgánica. Sin embargo, debido a la baja temperatura se espera menor mineralización de la materia orgánica. De esta forma, los suelos pueden proporcionar menos cantidad de nitrógeno $(N)$ mineral, respecto a los requerimientos de la vid. Por eso, es necesaria la aplicación de nitrógeno que puede afectar la productividad de la vid y la composición de la uva. Este estudio tuvo como objetivo evaluar la productividad y la composición del mosto de la vid sometido a la aplicación de $N$ en suelos con alto contenido de materia orgánica y la relación con la temperatura y la pluviometría. El estudio fue realizado durante las campañas de los años 2011/12, 2012/13 y 2013/14, en un viñedo ubicado en el municipio de Agua Doce, Santa Catarina, región sur de Brasil. Los tratamientos fueron diferentes dosis de $N\left(0,20,40,80\right.$ e $\left.120 \mathrm{~kg} \mathrm{~N} \mathrm{ha}^{-1}\right)$, suministrados con urea. La dosis de máxima eficiencia técnica en la vid Cabernet Sauvignon fue alcanzada con $46 \mathrm{~kg} \mathrm{~N} \mathrm{ha}^{-1}$ año-1 en suelos con alto contenido de materia orgánica. El contenido de nitrógeno en las hojas fue un parámetro sensible a la aplicación de dosis de $N$ en el suelo es sensible a la distribución de las lluvias. El $N$ reduce el contenido de sólidos solubles totales en el mosto. Con base en los principales componentes analizados, los resultados indican una correlación entre el contenido de nitrógeno total en las hojas y la precipitación acumulada, así como entre los rendimientos y la temperatura.

Palabras clave: fertilización nitrogenada, análisis foliar, producción de uva, parámetros enológicos, Vitis vinifera.

1 Department of Soil Science of the Federal University of Santa Maria, Santa Maria, RS, Brazil.

2 Department of Rural Engineering of the Federal University of Santa Catarina, Rodovia Admar Gonzaga 1346, Florianópolis, SC, Brazil.

3 Department of Soil Science of the Federal University of Rio Grande do Sul, Bento Gonçalves Avenue 7712, Porto Alegre, RS, Brazil.

* Corresponding author. linconfa@hotmail.com

Fecha de Recepción: 09 Julio, 2018.

Fecha de Aceptación: 30 Abril, 2019. 


\section{Introduction}

Vineyards located in high altitude regions are typically installed in soils with high organic matter content, which hypothetically provide adequate availability of mineral nitrogen $(\mathrm{N})$ to grapevines. However, as the air and soil temperatures are low, lower microbial activity and slow mineralization of organic matter and residues deposited on the soil surface is expected (Burns et al., 2016). Thus, the application of $\mathrm{N}$ sources is necessary to meet the needs of the grapevines, and urea is typically preferred because it has the lowest cost per unit of N (Queiroz et al., 2011).

Urea applied to soil is hydrolyzed by extracellular urease enzymes produced by soil microorganisms such as bacteria, actinobacteria and fungi. From this hydrolysis, ammonium carbonate $\left(\left(\mathrm{NH}_{4}{ }^{+}\right)_{2} \mathrm{CO}_{3}\right)$ is produced and it is unstable in the soil. In contact with water molecules, ammonium carbonate decomposes into bicarbonate, hydroxyl and ammonium. The bicarbonate may possibly decompose into carbon dioxide and hydroxyl. If ammonium reacts with hydroxyl, ammonia may be prompted by the atmosphere (Brunetto et al., 2016). However, part of this ammonium can be transformed into nitrate, which is the most stable mineral form of $\mathrm{N}$ in the soil. Ammonium and nitrate can be absorbed when they are close to the outer surface of the roots of the grapevines, increasing the concentration of $\mathrm{N}$ in plants, especially in annual organs in periods of growth and grape production (Agnelli et al., 2014).

The concentration of $\mathrm{N}$ in the grapevine is commonly diagnosed through leaf analysis, preferably collected at full flowering. The success of the diagnosis in this phenological stage is due to the greater emission of young roots, which are responsible for the uptake of water and nutrients, and the intense cell division of organs, such as those of the shoots, promoting increased dry matter (Zapata et al., 2004; Schreiner \& Scagel, 2006). Part of the $\mathrm{N}$ present in the leaves can be redistributed in greater amount to other growing annual organs, such as branches of the year or grape clusters (Brunetto et al., 2009). It may also reach perennial organs, such as stem, branches of more than one year and especially roots, but in lower amounts (Brunetto et al., 2014). It is also possible to collect leaves at veraison (CQFS-RS/SC, 2016), but the leaves collected at this phenological stage tend to have a lower concentration of $\mathrm{N}$ in relation to those collected at full flowering. For this reason, the method is less sensitive in diagnosing the increase of $\mathrm{N}$ content in the grapevine. Thus, a lower correlation of $\mathrm{N}$ concentration in leaves with yield parameters and must composition is expected (Brunetto et al., 2009).

$\mathrm{N}$ absorbed by grapevines and its increase within the plants can accelerate the ripening of the branches, which favors the emission of fertile buds (Anzanello et al., 2012), budding and increased values of yield parameters, such as average cluster weight, number of clusters per plant and yield (Brunetto et al., 2009). However, the composition of the grape and must changes with increasing yield. Grapes and must derived from grapevines subjected to the application of high doses of $\mathrm{N}$ exhibited the highest values of $\mathrm{N}$ forms and titratable acidity, but the lowest concentrations of total soluble solids (TSS) and anthocyanins (Cheng et al., 2014).

In regions of high altitude and high volume of rainfall, it is likely that part of the mineral $\mathrm{N}$ derived from the fertilizer, or even native soil $\mathrm{N}$ is lost by surface runoff or leaching, especially in the form of nitrate (Barlow et al., 2009; Lorensini et al., 2012; Sorrenti \&Toselli, 2016), reducing the positive impact of fertilization on yield parameters, as well as grape and must composition (Cheng et al., 2014). Furthermore, low air and soil temperatures affect soil microbial activity, reducing soil $\mathrm{N}$ mineralization (Burns et al., 2016). On the other hand, frequent rainfall tends to increase canopy moisture, stimulating the incidence of foliar fungal diseases caused by nitrogen fertilization, especially in grapevines with higher vegetative growth (Duchêne et al., 2001).

Therefore, calibration studies on $\mathrm{N}$ doses and physiological and yield parameters are necessary to define the ideal $\mathrm{N}$ dose and the real impact of climatic variables on the yield and must composition in regions with potential for grapevine cultivation and the production of high quality wines. The aim of this study was to evaluate yield and must composition of grapevines subjected to the application of $\mathrm{N}$ in soil with high organic matter content and the relationship with temperature and rainfall.

\section{Material and methods}

\section{Location and treatments}

The study was conducted in crop seasons 2011/12, 2012/13 and 2013/14 in a vineyard in the 
city of Água Doce, located in the Midwestern region of the state of Santa Catarina (SC), southern Brazil

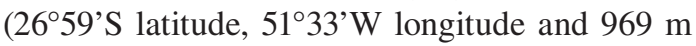
altitude). The cultivar was Cabernet Sauvignon (Vitis vinifera) grafted onto the Paulsen 1103 rootstock. The vineyard was installed in 2003 and conducted in espalier system. Planting density was 2299 plants ha $^{-1}$, with a spacing of $1.50 \mathrm{~m}$ between plants and $2.90 \mathrm{~m}$ between rows. The climate of the region was classified as humid mesothermal (Cfb), according to Köppen classification, with an average annual temperature of $16.6^{\circ} \mathrm{C}$ and rainfall ranging from 1000 to $1900 \mathrm{~mm}$ year $^{-1}$. There was a weather station nearby to collect data such as temperature and rainfall during the evaluation period (crop seasons). Non-residual herbicide was used to desiccate the vegetation in the planting rows. Between the planting rows, cover crops such as Paspalum notatum, Trifolium repens L. and Lolium multiflorum were predominant. Throughout the cycle of the grapevine, the cover crops were manually mowed and the residues deposited on the soil surface.

The soil was classified as Typic Dystrudepts (Soil Survey Staff, 2014), located in smooth undulating relief with the following physical and chemical characteristics at $0.0-0.20 \mathrm{~m}$ prior to the installation of the experiment: $109.5 \mathrm{~g} \mathrm{~kg}^{-1}$ of sand, $444 \mathrm{~g} \mathrm{~kg}^{-1}$ of silt and $451.5 \mathrm{~g} \mathrm{~kg}^{-1}$ of clay (Tedesco et al., 1995); $62.45 \mathrm{~g} \mathrm{~kg}^{-1}$ of organic matter (Walkley Black method), $6.14 \mathrm{pH}$ in water (1:1 ratio); 2.32 and $122.45 \mathrm{mg} \mathrm{kg}^{-1}$ of available $\mathrm{P}$ and $\mathrm{K}$, respectively (both extracted by Mehlich-1); 0.0, 7.05 and 5.75 $\mathrm{cmol}_{\mathrm{c}} \mathrm{kg}^{-1}$ of $\mathrm{Al}, \mathrm{Ca}$ and $\mathrm{Mg}$, respectively (extracted by $\mathrm{KCl} 1 \mathrm{~mol} \mathrm{~L}^{-1}$ ) (Tedesco et al., 1995).

The experimental design was a randomized block with four replicates. Each replicate consisted of five plants. The three central plants of each replicate were evaluated. The treatments consisted of $\mathrm{N}$ doses $\left(0,20,40,80\right.$ and $120 \mathrm{~kg} \mathrm{~N}^{-1}$ year-1), $^{-1}$, whose source was urea $(45 \% \mathrm{~N})$, applied in the area of crown projection on the soil surface, without incorporation. The doses were applied annually at budding, as suggested by Brunetto et al. (2009).

\section{Leaf collection and nitrogen analysis}

At full flowering and veraison, ten fully expanded leaves opposite the first cluster (counted from the apex) were collected in branches of the year of each plant in each crop season. The leaves were dried in a forced air circulation oven at $65^{\circ} \mathrm{C}$ until constant dry mass was obtained and then ground in a Willey-type mill. The tissue was subjected to sulfur digestion and then distilled using a microKjeldahl N distiller (Te 0363, Tecnal, São Paulo, Brazil) for the determination of total $\mathrm{N}$ (Tedesco et al., 1995).

\section{Yield parameters and must composition}

At harvesting, the number of clusters per plant was counted and all clusters were weighed to determine the yield per plant and yield. Berries were collected in the upper, middle and lower portions of five clusters per plant, and then crushed. The following chemical parameters were determined in the must: $\mathrm{pH}$ using $\mathrm{pH}$ meter (AD8000, ADWA, Szeged, Hungary) calibrated with buffer solutions of pH 4.0 and pH 7.0; total soluble solids (TSS) using a digital temperature-compensated refractometer (RTD 45, Instrutherm, São Paulo, Brazil); titratable acidity (TA) by titration ( $0.1 \mathrm{~N}$ of $\mathrm{NaOH})$ using phenolphthalein (1\%); and tartaric acid by high performance liquid chromatography (HPLC).

\section{Statistical analyses}

The results were submitted to analysis of variance, using Sisvar software, version 5.6 (Ferreira, 2003). Regression analysis was performed when the differences were significant by the $\mathrm{F}$ test at $5 \%$. Principal component analysis (PCA) based on the average of the variables (total $\mathrm{N}$ content in leaf, yield, average cluster weight, number of clusters per plant, $\mathrm{pH}$, TSS, TA and tartaric acid) was also done using CANOCO software, version 4.5 (Ter Braak and Smilauer, 2002). Equation 1 was used to determine maximum technical efficiency (MTE) of the dose:

$$
\mathrm{MET}=-\frac{\mathrm{b}_{1}}{2 \mathrm{~b}_{2}}
$$

Equation 1

Where: $\mathrm{b} 1=\mathrm{x}$, and $\mathrm{b} 2=\mathrm{x}^{2}$;

\section{Results and discussion}

\section{$\mathrm{N}$ concentration in leaf}

The applications of $\mathrm{N}$ doses in the soil increased the total $\mathrm{N}$ contents quadratically in leaves of Cabernet Sauvignon grapevines collected at full 
flowering in crop seasons 2011/12 and 2013/14, and in leaves collected at veraison in 2012/13 and 2013/14 (Table 1). The increase in $\mathrm{N}$ concentration in leaves at full flowering occurred with the increase of $\mathrm{N}$ dose up to $80 \mathrm{~kg} \mathrm{~N} \mathrm{ha}^{-1}$ in crop season 2011/12 and up to $60 \mathrm{~kg} \mathrm{~N} \mathrm{ha}^{-1}$ in 2013/14. This increase in $\mathrm{N}$ in the leaf tissue indicates that addition of nitrogen fertilizer can increase leaf $\mathrm{N}$ content even in soils with high organic matter content. The response to $\mathrm{N}$ doses in the soil may be due to the low temperature of the air and soil, inhibiting microorganisms (Burns et al., 2016), but also because of the physical protection of soil organic matter, since the soil presents $451.5 \mathrm{~g} \mathrm{~kg}^{-1}$ of clay, which favors the formation of microaggregates. On the other hand,
$\mathrm{N}$ added to the soil may be related to the high root emission capacity of grapevines during budding and especially at flowering (Radville et al., 2016). This potentiates the uptake of water and nutrients, such as $\mathrm{N}$ present in soil, or of $\mathrm{N}$ forms resulting from the application of urea at budding (Brunetto et al., 2016).

The increase of $\mathrm{N}$ forms in the soil can stimulate the emission of younger roots by the plants, increasing the volume of soil explored by the root system, which also potentiates nutrient uptake (Radville et al., 2016). However, much of the $\mathrm{N}$ absorbed by the grapevines is typically derived from the mineralization of organic matter and decomposing residues of the grapevines themselves or of the

Table 1. Total $\mathrm{N}$ content in leaves collected at flowering and veraison, yield parameters and must composition in 'Cabernet Sauvignon' grapevines subjected to applications of 0, 20, 40, 80 and $120 \mathrm{~kg} \mathrm{~N} \mathrm{ha}^{-1}$ year-1 during crop seasons 2011/12, 2012/13 and 2013/14.

\begin{tabular}{|c|c|c|c|c|c|c|c|}
\hline \multirow{2}{*}{ Variables } & \multicolumn{5}{|c|}{ N Dose $\left(\mathrm{kg} \mathrm{N} \mathrm{ha}^{-1}\right.$ year $\left.^{-1}\right)$} & \multirow{2}{*}{ Equation } & \multirow{2}{*}{$\mathrm{R}^{2}$} \\
\hline & 0 & 20 & 40 & 80 & 120 & & \\
\hline \multicolumn{8}{|c|}{ Crop Season 2011/12 } \\
\hline Total $\mathrm{N}$ in leaf - flowering $\left(\mathrm{g} \mathrm{kg}^{-1}\right)$ & 51.96 & 75.38 & 57.68 & 59.68 & 60.19 & $\mathrm{y}=58.83+0.16 \mathrm{x}-0.001 \mathrm{x}^{2}$ & $0.70 *$ \\
\hline Number of clusters per plant & 14 & 15 & 14 & 14 & 16 & - & ns \\
\hline Average cluster weight (g) & 176.05 & 189.68 & 207.05 & 191.34 & 213.54 & - & ns \\
\hline Yield per plant $(\mathrm{kg})$ & 2.45 & 2.91 & 3.02 & 2.75 & 3.54 & - & ns \\
\hline Total soluble solids ( $\left.{ }^{\circ} \mathrm{Brix}\right)$ & 17.05 & 17.31 & 17.45 & 17.5 & 17.38 & $\mathrm{y}=17.08+0.01 \mathrm{x}-0.000084 \mathrm{x}^{2}$ & $0.96^{*}$ \\
\hline $\mathrm{pH}$ & 3.18 & 3.2 & 3.21 & 3.22 & 3.2 & $\mathrm{y}=3.18+0.001 \mathrm{x}-0.000007 \mathrm{x}^{2}$ & $0.97 *$ \\
\hline Titratable acidity $\left(\mathrm{meq} \mathrm{L} \mathrm{L}^{-1}\right)$ & 153 & 147.75 & 145.75 & 145.75 & 145.5 & - & ns \\
\hline Tartaric acid $\left(m e q ~ L^{-1}\right)$ & 1.14 & 1.09 & 1.09 & 1.09 & 1.04 & $y=1.12-0.000644 x$ & $0.76^{*}$ \\
\hline \multicolumn{8}{|c|}{ Crop Season 2012/13 } \\
\hline Total $\mathrm{N}$ in leaf - flowering $\left(\mathrm{g} \mathrm{kg}^{-1}\right)$ & 61.81 & 62.17 & 62.31 & 65.22 & 65.47 & - & ns \\
\hline Total $\mathrm{N}$ in leaf - veraison $\left(\mathrm{g} \mathrm{kg}^{-1}\right)$ & 46.18 & 48.76 & 48.76 & 56.08 & 48.51 & $\mathrm{y}=45.09+0.23 \mathrm{x}-0.0016 \mathrm{x}^{2}$ & $0.66^{*}$ \\
\hline Number of clusters per plant & 11 & 14 & 14 & 11 & 10 & $y=11.52+0.091 x-0.0009 x^{2}$ & $0.67 *$ \\
\hline Average cluster weight (g) & 70.88 & 91.03 & 77.76 & 78.81 & 58 & $y=74.49+0.42 x-0.0047 x^{2}$ & $0.74^{*}$ \\
\hline Yield per plant $(\mathrm{kg})$ & 0.76 & 1.29 & 1.13 & 0.87 & 0.56 & $y=0.896+0.01059 x-0.000115 x^{2}$ & $0.73^{*}$ \\
\hline Total soluble solids ( $\left.{ }^{\circ} \mathrm{Brix}\right)$ & 15.53 & 16.43 & 17.13 & 17.28 & 15.58 & $y=15.46+0.062 x-0.0006 x^{2}$ & $0.99 *$ \\
\hline $\mathrm{pH}$ & 2.93 & 3.05 & 3.06 & 3.07 & 2.99 & $y=2.95+0.0044 x-0.000034 x^{2}$ & $0.91 *$ \\
\hline Titratable acidity $(\mathrm{meq} \mathrm{L}-1)$ & 215 & 203 & 192.25 & 190.25 & 208.5 & $\mathrm{y}=215.83-0.85 \mathrm{x}+0.0067 \mathrm{x}^{2}$ & $0.99 *$ \\
\hline Tartaric acid $\left(m e q ~ L^{-1}\right)$ & 1.55 & 1.52 & 1.46 & 1.46 & 1.46 & $y=1.55-0.0023 x+0.000013 x^{2}$ & $0.93 *$ \\
\hline \multicolumn{8}{|c|}{ Crop Season 2013/14 } \\
\hline Total $\mathrm{N}$ in leaf - flowering $\left(\mathrm{g} \mathrm{kg}^{-1}\right)$ & 31.68 & 33.76 & 37.21 & 37.92 & 46.48 & $y=32.36+0.056 x+0.00047 x^{2}$ & $0.94 *$ \\
\hline Total $\mathrm{N}$ in leaf - veraison $\left(\mathrm{g} \mathrm{kg}^{-1}\right)$ & 37.84 & 49.56 & 51.47 & 45.4 & 40.99 & $y=40.51+0.34 x-0.0029 x^{2}$ & $0.70 *$ \\
\hline Number of clusters per plant & 18 & 23 & 19 & 20 & 24 & - & ns \\
\hline Average cluster weight (g) & 109.65 & 119.41 & 119.51 & 114.06 & 122.64 & - & ns \\
\hline Yield per plant $(\mathrm{kg})$ & 1.97 & 2.79 & 2.24 & 2.31 & 2.92 & - & ns \\
\hline Total soluble solids ( ${ }^{\circ}$ Brix) & 19.35 & 19.48 & 19.43 & 19.7 & 19.38 & - & ns \\
\hline $\mathrm{pH}$ & 3.24 & 3.34 & 3.36 & 3.39 & 3.31 & $y=3.25+0.0041 x-0.00003 x^{2}$ & $0.96^{*}$ \\
\hline Titratable acidity (meq L-1) & 140.75 & 138.8 & 134.75 & 133.9 & 131.85 & $y=140.76-0.14 x+0.00059 x^{2}$ & $0.95^{*}$ \\
\hline Tartaric acid $\left(m e q L^{-1}\right)$ & 1.06 & 1.04 & 1.02 & 1.01 & 0.98 & $y=1.05-0.00083 x+0.000002 x^{2}$ & $0.97 *$ \\
\hline
\end{tabular}

$\mathrm{ns}=$ not significant $*$ * significant with $\mathrm{P}<0.05$. 
plants that co-inhabit the vineyards (Brunetto et al., 2014). This may happen because the addition of $\mathrm{N}$ doses via urea can stimulate the activity of the soil microbial population, increasing the mineralization of organic matter and plant residues. Thus, $\mathrm{N}$ forms derived from the fertilizer in soil and in solution can be diluted, which increases the probability of $\mathrm{N}$ uptake derived from sources other than fertilizer (Yang et al., 2017). Part of the $\mathrm{N}$ from the fertilizer, especially ammonium or even nitrate, can be adsorbed to reactive inorganic particles or complexed to the functional groups of organic compounds in soil, decreasing their concentration in soil solution (Barlow et al., 2009).

During flowering, the leaves show intense cell division and elongation, which increases dry matter and, as a result, these organs become drains for nutrients (e.g., N) (Schreiner \& Scagel, 2006; Brunetto et al., 2014). Similarly, N distribution in the leaves can be stimulated by increased leaf area, which raises transpiration and transport of $\mathrm{N}$ forms to the leaves. Furthermore, a concentration gradient is generated near the root system, which potentiates the approximation of $\mathrm{N}$ forms, such as nitrate, through mass flow, increasing the probability of uptake by the root system (Barlow et al., 2009).

The leaves collected at veraison were also sensitive in detecting the increase of $\mathrm{N}$ in the plants subjected to applications of increasing $\mathrm{N}$ doses in soil (Table 1), most likely derived from the fertilizer and other soil sources (Brunetto et al., 2014; Brunetto et al., 2016). The increase of $\mathrm{N}$ content in the tissue at veraison increased even at doses of 76 and 59 $\mathrm{kg}$ of $\mathrm{N} \mathrm{ha}^{-1}$ in crop seasons 2012/13 and 2013/14, respectively. However, $\mathrm{N}$ concentrations determined in leaves collected at veraison in 2012/13 were lower than those found in leaves collected at flowering. This can be attributed to reduced cell division in the leaves, which decreases the need for nutrients (Marschner, 2012; Agnelli et al., 2014). The lowest rate of uptake is related to transpiration, which can also reduce the flow of water and nutrients within the plant and future approximation of $\mathrm{N}$ forms to the outer surface of the roots (Radville et al., 2016). However, the lowest $\mathrm{N}$ concentration in leaves collected at veraison can be explained by the redistribution of part of the $\mathrm{N}$ in the leaves to the clusters, which have intense cell division and increased dry matter (Brunetto et al., 2009). This is because some of the nitrogen compounds present in the leaves, such as amino acids (Marschner, 2012), can be degraded and $\mathrm{N}$ can be redistributed to other organs of the grapevine, such as branches of the year, stem, roots and especially clusters (Zapata et al., 2004).

It should be noted that $\mathrm{N}$ concentrations in leaves collected at flowering or veraison were distinct among the crop seasons (Table 1). In crop season 2012/13, N concentration in leaves collected at flowering was higher than that found in 2013/14. The same was observed in the leaves collected at veraison in 2012/13 compared to 2013/14. The highest accumulated rainfall (1906 mm), which occurred in 2013/14 (mainly in October, November and December), may have contributed to this result (Figure 1). Rainfall favors the maintenance of soil moisture. Together with mild temperatures $\left(25^{\circ} \mathrm{C}\right)$, it stimulates the action of extracellular enzymes such as urease, which degrade the urea molecule, increasing the infiltration of $\mathrm{N}$ forms in soil, both of the fertilizer and of the mineralization of organic matter or decomposing residues. This process reduces $\mathrm{N}$ losses by volatilization in the form of ammonia (Lorensini et al., 2012), enhancing the uptake of $\mathrm{N}$ forms by the grapevines (Brunetto et al., 2016). There was high rainfall $(1400 \mathrm{~mm})$ in crop season $2012 / 13$, but it was $25 \%$ lower than in 2013/14 . Thus, we believe that the greatest increase of $\mathrm{N}$ in the leaves collected in 2012/2013 is a consequence of the best soil water balance, which may have stimulated the emission of young roots by the grapevines, enabling the exploration of a greater volume of soil, increasing the potential for water and nutrient uptake (Radville et al., 2016).

\section{Yield parameters}

The applications of $\mathrm{N}$ doses increased the number of clusters per plant and average cluster weight in a quadratic manner, which was reflected in increased yield per plant (Table 1) and yield in crop season 2012/13 (Figure 2a). The dose of maximum technical efficiency was obtained with the application of $46 \mathrm{~kg} \mathrm{~N}^{-1}$ (Figure 2a). In grapevines subjected to doses greater than $40 \mathrm{~kg} \mathrm{~N} \mathrm{ha}^{-1}$ (80 and $120 \mathrm{~kg} \mathrm{~N} \mathrm{ha}^{-1}$ ), we found a decrease in the number of clusters per plant, average cluster weight, yield per plant (Table 1) and yield (Figure 2a). The response of grapevines to low $\mathrm{N}$ doses (20 and $40 \mathrm{~kg} \mathrm{~N} \mathrm{ha}^{-1}$ ) may be associated to the high organic matter content in soil at $0.0-0.20 \mathrm{~m}$ $\left(62.45 \mathrm{~g} \mathrm{~kg}^{-1}\right)$. 


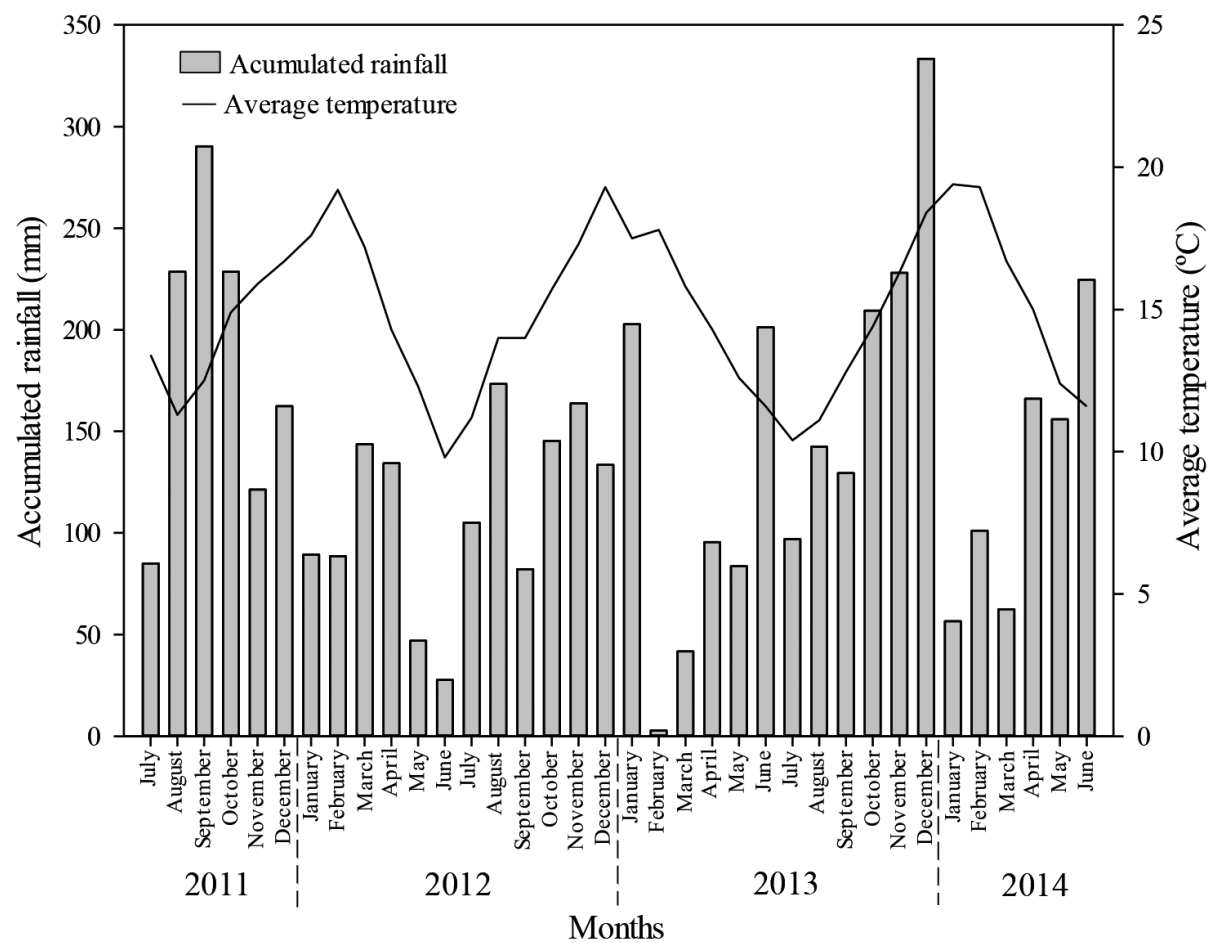

Figure 1. Accumulated rainfall and average temperature in the experimental area in Água Doce-SC during crop seasons 2011/12, 2012/13 and 2013/14.

Part of the soil organic matter and plant residues deposited on the soil may be mineralized by the microbial population, increasing the concentration of $\mathrm{N}$ forms in soil solution, which can be absorbed by the grapevines (Barlow et al., 2009; Burns et al., 2016), reducing the use of $\mathrm{N}$ derived from the fertilizer (Agnelli et al., 2014; Brunetto et al., 2016). However, part of the $\mathrm{N}$ derived from higher $\mathrm{N}$ doses may be lost in vineyards by surface runoff (Sorrenti \& Toselli, 2016) leaching (Lorensini et al., 2012) and volatilization as ammonia and nitrous oxide (Lorensini et al., 2012; Hannam et al., 2016), reducing the amount of $\mathrm{N}$ derived from the fertilizer used by the plants (Brunetto et al., 2016).

In this study, we believe that the amounts of $\mathrm{N}$ derived from the fertilizer lost were small due to the smooth undulating relief of the vineyard, causing reduced runoff of solution on the soil surface. As the soil has high organic matter content (62.45 $\mathrm{g} \mathrm{kg}^{-1}$ ), most $\mathrm{N}$ forms derived from the fertilizer were possibly complexed by soil organic matter (Yang et al., 2017). This decreases leaching as well as volatilization losses, since the average temperatures throughout the year in the region are relatively low (Figure 1).
The average air temperatures in September, which coincided with the budding period in which the $\mathrm{N}$ doses were applied, were between 12 and $14^{\circ} \mathrm{C}$ in crop seasons evaluated in this study. However, mild temperatures reflect the low release of $\mathrm{N}$ from soil organic matter (Burns et al., 2016). In this study, the losses of $\mathrm{N}$ derived from the fertilizer in the vineyard were higher in the grapevines subjected to the highest $\mathrm{N}$ doses, which showed a reduction in the number of clusters per plant, average cluster weight, yield per plant (Table 1) and yield (Figure 2a). This may be associated to the incidence of diseases in these plants, since part of the $\mathrm{N}$ derived from the fertilizer absorbed by the grapevines and diagnosed by the analysis of leaves collected at flowering and veraison (Figure 2b) may have stimulated vegetative growth. This increased vegetative growth may have reduced the incidence of solar radiation in plants and air circulation, stimulating the occurrence of fungal diseases in flowers, during flowering (Duchêne et al., 2001).

In crop seasons 2011/2012 and 2013/14, the application of $\mathrm{N}$ doses did not affect the number of clusters per plant, average cluster weight, yield per plant (Table 1) and yield (8.14 and 6.71 Mg 

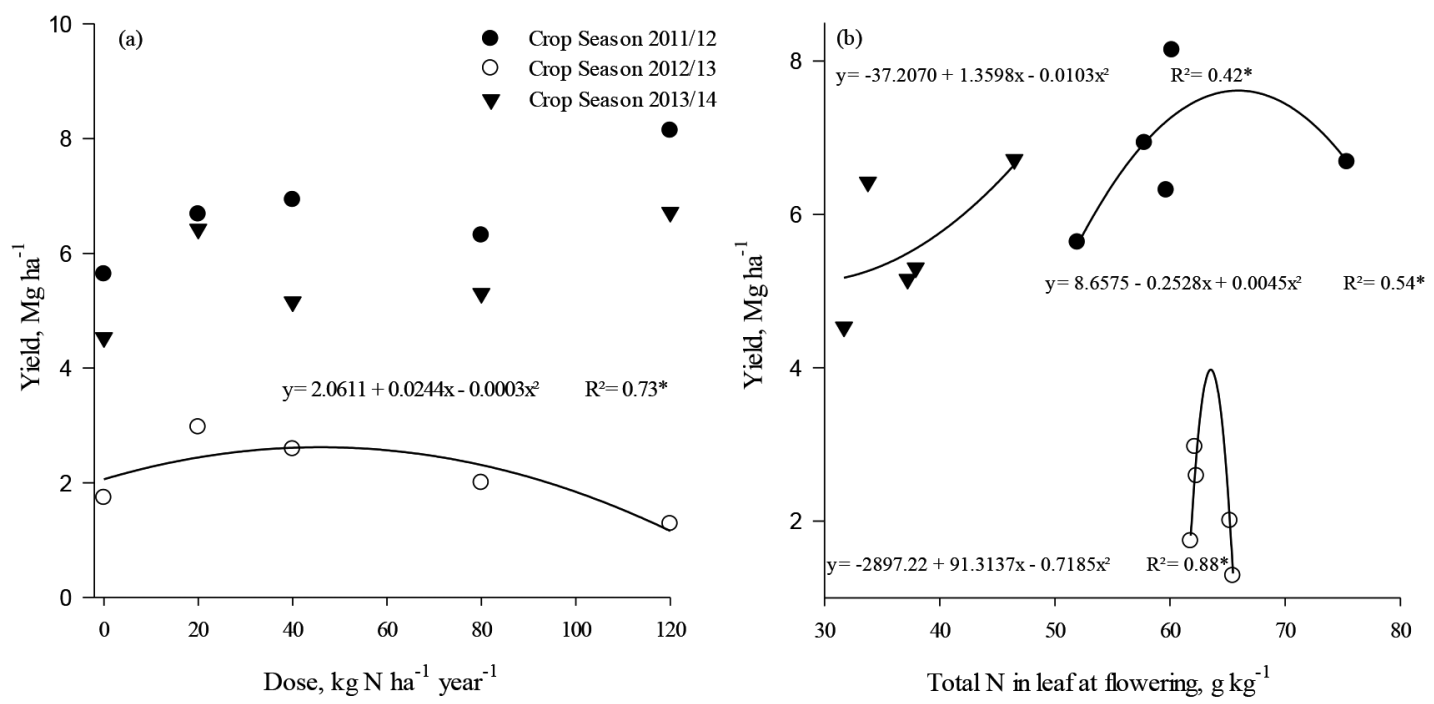

Figure 2. Relationship between yield and nitrogen dose (a) and yield and total nitrogen content in fully expanded leaves collected at flowering (b), in grapevines subjected to the application of 0, 20,40, 80 and $120 \mathrm{~kg} \mathrm{~N} \mathrm{ha}^{-1}$ year-1 during crop seasons 2011/12, 2012/13 and 2013/14.

$\mathrm{ha}^{-1}$ ) (Figure 2a). Such yields are typically found in Cabernet Sauvignon vineyards conducted in espalier (Brunetto et al., 2009). The low response of grapevines to $\mathrm{N}$ doses reinforces the possibility of the contribution of $\mathrm{N}$ forms derived from sources other than fertilizer, as well as $\mathrm{N}$ translocation from plant reserve organs. The mineralization of soil organic matter and the decomposition of grapevine residues (pruning material) or of decomposing cover crop residues deposited on the soil are also considerable sources of $\mathrm{N}$ contribution (Brunetto et al., 2014; Burns et al., 2016). Additionally, the presence of white clover (Trifolium repens L.) between the rows of the vineyards may have caused biological fixation of atmospheric $\mathrm{N}$, increasing the concentration in soil and possibly being absorbed by the root system (Radville et al., 2016). It should be noted that the soil has high levels of organic matter, which together with the absence of toxic aluminum, favors soil microbial activity.

\section{Must composition}

TSS contents increased in a quadratic manner with increasing $\mathrm{N}$ doses applied to grapevines in crop seasons 2011/12 and 2012/13, and were not affected by $\mathrm{N}$ doses in 2013/14 (Table 1). In crop seasons 2011/12 and 2012/13, even though we found a statistically significant difference between the values of TSS in the must of the grapevines subjected to $\mathrm{N}$ doses, the values were very close. This is expected and consistent, since there was an increase in cluster weight (Table 1) (Cheng et al., 2014). This normally promotes the dilution of sugars due to the effect of accumulated rainfall and, consequently, of TSS values (Hannam et al., 2016).

The applications of $\mathrm{N}$ doses increased $\mathrm{pH}$ in must quadratically in crop seasons 2011/12, 2012/13 and 2013/14 (Table 1). However, the increase of $\mathrm{N}$ doses in the soil reduced TA in must quadratically in 2012/13 and 2013/14 and tartaric acid in all three crop seasons. This was probably due to the relationship between $\mathrm{pH}$ and acidity, which depend on the ionization capacity and acid concentration of the medium (Brunetto et al., 2009). In 2012/13, which had the lowest yield, TA values exceeded $200 \mathrm{meq} \mathrm{L}^{-1}$, approximately $25 \%$ more than in the other two crop seasons.

\section{Principal Component Analysis (PCA)}

Principal component analysis (PCA) for crop season 2011/12 showed that the sum of component variability accounts for $86.31 \%$ of the variability of the original results (Figure 3a), of which 56.8\% was explained by factor 1 and $19.53 \%$ by factor 2 . The distribution of the points in each group in factor 1 is associated to $\mathrm{N}$ doses, separating the doses of $20,40,80$ and $120 \mathrm{~kg} \mathrm{~N} \mathrm{ha}^{-1}$ from the treatment without $\mathrm{N}\left(0 \mathrm{~kg} \mathrm{~N} \mathrm{ha}^{-1}\right)$. The most influential 
variables for this separation in the group of $\mathrm{N}$ doses of $20,40,80$ and $120 \mathrm{~kg} \mathrm{~N}^{-1}$ were yield, number of clusters per plant, average cluster weight, total $\mathrm{N}$ in leaf at full flowering; and TSS and $\mathrm{pH}$ in the must. In the group without $\mathrm{N}$, the variables with the greatest contribution were TA and tartaric acid. In crop season 2012/13, the $\mathrm{N}$ doses formed different groups again, where the sum of the component variability explained $93.24 \%$ of the variability of the results, $56.93 \%$ explained by factor 1 and $36.31 \%$ by factor 2 (Figure 3b). Factor 1 separated the dose of $120 \mathrm{~kg} \mathrm{~N} \mathrm{ha}^{-1}$ and $0 \mathrm{~kg} \mathrm{~N} \mathrm{ha}^{-1}$ on the right side of the graph, where the most influential variables were total $\mathrm{N}$ in leaf at full flowering, tartaric acid and TA. In the group on the left side composed of doses 40,80 and $120 \mathrm{~kg} \mathrm{~N} \mathrm{ha}^{-1}$, the most influential variables were must, $\mathrm{pH}$, TSS, average cluster weight, number of clusters per plant and yield. The analysis of crop season 2013/14 showed that the sum of the component variability explains $83.20 \%$ of the variability of the results, of which $61.62 \%$ and $21.58 \%$ were explained by factor 1 and 2, respectively (Figure 3c). Thus, crop season 2013/14 had similar behavior to crop season 2011/12 regarding the separation of the groups according to $\mathrm{N}$ doses, and also in relation to the influence of the variables on the responses.

When crop seasons 2011/12, 2012/13 and 2013/14 were analyzed considering the climactic parameters (average temperature and accumulated
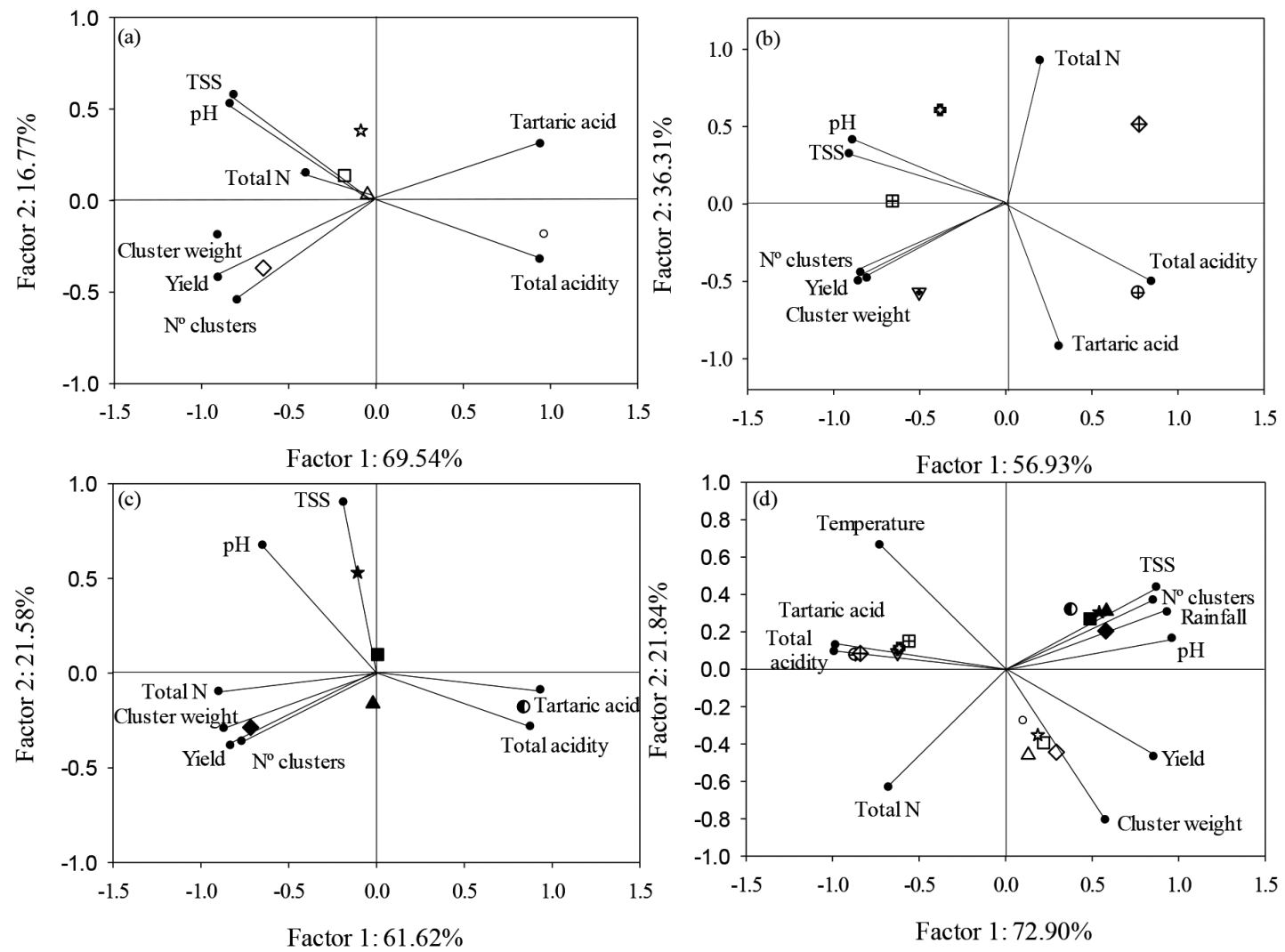

\begin{tabular}{|c|c|c|c|c|c|}
\hline \multicolumn{2}{|c|}{ Crop Season 2011/12 } & \multicolumn{2}{|c|}{ Crop Season 2012/13 } & \multicolumn{2}{|c|}{ Crop Season 2013/14 } \\
\hline o & $0 \mathrm{~kg} \mathrm{~N} \mathrm{ha}^{-1}$ & $\oplus$ & $0 \mathrm{~kg} \mathrm{~N} \mathrm{ha-1}$ & 0 & $0 \mathrm{~kg} \mathrm{~N} \mathrm{ha}{ }^{-1}$ \\
\hline$\triangle$ & $20 \mathrm{~kg} \mathrm{~N} \mathrm{ha}^{-1}$ & $\nabla$ & $20 \mathrm{~kg} \mathrm{~N} \mathrm{ha}^{-1}$ & $\Delta$ & $20 \mathrm{~kg} \mathrm{~N} \mathrm{ha}^{-1}$ \\
\hline$\square$ & $40 \mathrm{~kg} \mathrm{~N} \mathrm{ha}^{-1}$ & 田 & $40 \mathrm{~kg} \mathrm{~N} \mathrm{ha}^{-1}$ & $\mathbf{\square}$ & $40 \mathrm{~kg} \mathrm{~N} \mathrm{ha}^{-1}$ \\
\hline मे & $80 \mathrm{~kg} \mathrm{~N} \mathrm{ha}^{-1}$ & 4 & $80 \mathrm{~kg} \mathrm{~N} \mathrm{ha}^{-1}$ & $\star$ & $80 \mathrm{~kg} \mathrm{~N} \mathrm{ha}^{-1}$ \\
\hline$\diamond$ & $120 \mathrm{~kg} \mathrm{~N} \mathrm{ha}^{-1}$ & $\oplus$ & $120 \mathrm{~kg} \mathrm{~N} \mathrm{ha}^{-1}$ & $\diamond$ & $120 \mathrm{~kg} \mathrm{~N} \mathrm{ha}^{-1}$ \\
\hline
\end{tabular}

Figure 3. Relationship between principal component 1 (factor 1) and principal component 2 (factor 2) for yield, total N content in leaf and parameters of must composition in crop seasons 2011/12 (a), 2012/13 (b) 2013/14 (c), and the influence of temperature and rainfall on Cabernet Sauvignon grapevine behavior in the three crop seasons (d). 
rainfall), the sum of the component variability explained $94.74 \%$ of the variability in the original results, of which $72.9 \%$ was explained by factor 1 and $21.84 \%$ by factor 2 (Figure $3 d$ ). The separation of the points in each group in factor 1 is associated to the crop seasons, separating 2011/12 and 2013/14 from 2012/13. In this separation, the most influential variables for the group on the right side of the graph were TSS and $\mathrm{pH}$; number of clusters per plant and rainfall predominating in the crop season 2011/12, and yield and cluster weight for 2013/14. For the group on the left side of the graph, variables such as tartaric acid, TA and temperature stood out for crop season 2012/13, in addition to total $\mathrm{N}$ in leaf at full flowering for the same factor. Based on this joint analysis, opposite behavior between total $\mathrm{N}$ content in leaves collected at full flowering and accumulated rainfall was observed through negative linear correlation (Figure 3d). The relationship between total $\mathrm{N}$ in leaf and $\mathrm{N}$ dose was direct, that is, $\mathrm{N}$ contents in leaves at full flowering increased with increasing $\mathrm{N}$ doses. However, as there was high accumulated rainfall of 1647, 1431 and $1906 \mathrm{~mm}$ in 2011/12, 2012/13 and 2013/14, respectively, this may have potentiated losses of $\mathrm{N}$ forms in the soil. These losses may have occurred through runoff, or even by leaching of $\mathrm{N}^{-\mathrm{NO}_{3}}{ }^{-}$, reducing the use of $\mathrm{N}$ derived from the fertilizer (Lorensini et al., 2012; Sorrenti \& Toselli, 2016). In PCA, a negative linear correlation between yield and temperature was also verified (Figure 1d). This may have occurred due to oscillation in temperature during flowering, which may potentiate flower abortion, reducing fertile flowers and consequently yield parameters values such as cluster weight and yield (Cheng et al., 2014).

\section{Conclusion}

The dose of maximum technical efficiency in Cabernet Sauvignon was reached with $46 \mathrm{~kg} \mathrm{~N} \mathrm{ha}^{-1}$ year $^{-1}$ in soil with high organic matter content in crop season 2012/13. The detection of $\mathrm{N}$ content in leaf was sensitive to the application of $\mathrm{N}$ doses in soil, and underwent seasonal variation in relation to rainfall distribution. $\mathrm{N}$ doses reduced TSS contents in the must, due to the dilution of sugars by the increase in cluster and berry weight. The increase in rainfall decreased $\mathrm{N}$ content in leaf and the increase in temperature decreased yield. This demonstrates the effect of annual climatic variation on the treatments.

\section{Literature cited}

Agnelli, A.; Bol, R.; Trumborec, S.E.; Dixond, L.; Coccoe, S.; Corti, G.

2014. Carbon and nitrogen in soil and vine roots in harrowed and grass-covered vineyards. Agriculture Ecosystem Enviroment, 193: 70-82.

Anzanello, R.; Souza, P.V. D.; Coelho, P.F.

2012. Fenologia, Exigência térmica e produtividade de videiras "Niagara Branca", "Niagara Rosada" e "Concord" submetidas a duas safras por ciclo vegetativo. Revista Brasileira de Fruticultura, 34: 366-376.

Barlow, K.; Bond, W.; Holzapfel, B.; Smith, J.; Hutton, R.

2009. Nitrogen concentrations in soil solution and surface run-off on irrigated vineyards in Austrália. Australian Journal Grape Wine Research, 15: 31-143.

Brunetto, G.; Ceretta, C.A.; Kaminski, J.; Melo, G.W.B.; Girotto, E.; Trentin, E.E.; Lourenzi, C.R.; Vieira, R.C.B.; Gatiboni, L.C. 2009. Produção e composição química da uva de videiras Cabernet Sauvignon submetidas à adubação nitrogenada. Ciência Rural, 39: 2035-2041.

Brunetto, G.; Ceretta, C.A.; Melo, G.W.B.; Kaminski, J.; Trentin, G.; Girotto, E.; Ferreira, P.A.A.; Miotto, A.; Trivelin, P.C.O.

2014. Contribution of nitrogen from agricultural residues of rye to 'Niagara Rosada' grape nutrition. Science. Horticulturae, 169: 66-70.

Brunetto, G.; Ceretta, C.A.; Melo, G.W.B.; Girotto, E.; Ferreira, P.A.A.; Lourenzi, C.R.; Couto R.R.; Tassinari, A.; Knevitz
R.H.; Stefanello, L.O.S.; Lazzaretti, B.P.; Kulmann, M.S.S.; Carranca, C.

2016. Contribution of nitrogen from urea applied at different rates and times on grapevine nutrition. Scientia Horticulturae, 207: 1-6.

Burns, K.N.; Bokulich, N.A.; Cantu, D.; Greenhut, R.F.; Kluepfel, D.A.; Geen, A.T.O.; Strauss, S.L.; Steenwerth, K.L. 2016. Vineyard soil bacterial diversity and composition revealed by $16 \mathrm{~S}$ rRNA genes: Differentiation by vineyard management. Soil Biology \&amp; Biochemistry, 103: 337-348.

Cheng, G.; He, N.; Yue, X.; Wang, J.; Zhang, W.

2014. Effects of climatic conditions and soil properties on Cabernet Sauvignon berry growth and anthocyanin profiles. Molecules, 19: 13683-13703.

CQFS-RS/SC. Comissão de Química e fertilidade do solo - RS/SC 2016. Manual de calagem e adubação para os estados do Rio Grande do Sul e de Santa Catarina. SBSC - Núcleo Regional Sul/UFRGS, Porto Alegre, Brazil. 376 p.

Duchêne, E.; Schneider, C.; Gaudillère, J.P. 2001. Effects of nitrogen nutrition timing on fruit set of grapevine cv 'Grenache'. Vitis, 40: 45-46.

Ferreira, D.F.

2003. Programa de análises estatísticas (Statistical Analysis Software) e planejamento de experimentos. Lavras: UFLA. 
Hannam, K.D.; Neilsen, G.H.; Forge, T.A.; Neilsen, D.; Losso, I.; Jones, M.D.; Nichol, C.; Fentabil, M.M.

2016. Irrigation practices, nutrient applications, and mulches affect soil nutrient dynamics in a young Merlot (Vitis vinifera L.) vineyard. Canadian Journal of Soil Science, 36: 23-36. Lorensini, F.; Ceretta, C.A.; Girotto, E.; Cerini, J.B.; Lourenzi, C.R.; De Conti, L.; Trindade, M.M.; Melo, G.W.B.; Brunetto, G. 2012. Lixiviação e volatilização de nitrogênio em um Argissolo cultivado com videira submetida à adubação nitrogenada. Ciência Rural, 42: 1173-1179.

Marschner, P.

2012. Marschner's Mineral Nutrition of Higher Plants. Amsterdam, $672 \mathrm{p}$.

Queiroz, A.M.D.E.; Souza, C.H.E.; Machado, V.J.; Lana,

R.M.Q.; Korndorfer, G.H.; Silva, A.A.

2011. Avaliação de diferentes fontes e doses de nitrogênio na adubação da cultura do milho. Revista Brasileira de Milho e Sorgo, 10: 257-266.

Radville, L.; Bauerle, T.L.; Comas, L.H.; Marchetto, K.A.;

Lakso, A.N.; Smart, D.R.; Dunst, R.M.

2016. Limited linkages of aboveground and belowground phenology: A study in grape 1. American Journal of Botany, 103: 1897-1911.
Schreiner, R.P.; Scagel, C.F.

2006. Nutrient uptake and distribution in a mature "pinot noir' vineyard. Hortscience, 41: 336-345.

Soil Survey Staff.

2014. Keys to Soil Taxonomy.12ed. USDA-NRCS, Washington, DC, USA.

Sorrenti, G.; Toselli, M.

2016. Soil leaching as affected by the amendment with biochar and compost. Agriculture, Ecosystems and Environment, 226: 56-64.

Tedesco, M.J.; Gianello, C.; Bissani, C.A.; Bohnen, H.; Volkweiss, S.J.

1995. Análise do solo, planta e outros materiais. UFRGS, Porto Alegre,Brazil. 174 p.

Ter Braak, C.J.F.; Smilauer, P.

2002. Canoco reference manual and cano draw for windows user's guide: software for canonical community ordination (version 4.5). ithaca, microcomputer power. $500 \mathrm{p}$.

Zapata, C.; Dele, E.; Chaillou, S.; Magne, C.

2004. Partitioning and mobilization of starch and $\mathrm{N}$ reserves in grapevine (Vitis vinifera L.). Journal of Plant Physiology, 161: 1031-1040. 